\title{
The Setting: Land, economics and development in the Southern Highlands
}

\section{Bryant Allen}

Southern Highlands Province (SHP) is located almost in the middle of the mainland of Papua New Guinea. It is on the south-western end of the Highlands Highway and subject to the vicissitudes of landslides, bridge failures, potholes and criminal activity along the whole $600 \mathrm{~km}$ of the highway to Lae.

The province is $25,698 \mathrm{~km}^{2}$ in area and is the eighth largest province in terms of land area in Papua New Guinea. Land in the SHP ranges from below $600 \mathrm{~m}$ to over $2800 \mathrm{~m}$ in altitude. Land above $2800 \mathrm{~m}$ is not used for agriculture in Papua New Guinea and is usually not permanently occupied, although it is used extensively for hunting and harvesting pandanus, an important seasonal food source. Around 14 per cent of SHP is below $600 \mathrm{~m}$ altitude and just over five per cent is above $2800 \mathrm{~m}$ (Table 3.1).

Seventy-two per cent of SHP land is not in use for agriculture. It is either too high too cold, too cloudy, too steep or receives too much rain. Agriculture is concentrated between $1200 \mathrm{~m}$ and $2400 \mathrm{~m}$ above sea level (Table 3.1). Although only 30 per cent of the total land area is located between 1200 and $1800 \mathrm{~m}$ above sea level, 54 per cent of the land in use for agriculture is found in this altitude zone. Similarly, only 14 per cent of the province is between 1800 and $2400 \mathrm{~m}$ above sea level, but 22 per cent of the land in use is at this altitude. Conversely, of the $3600 \mathrm{~km}^{2}$ of land below $600 \mathrm{~m}$, only $219 \mathrm{~km}^{2}$, or three per cent, is in use. People are even more concentrated by altitude zone, with just over 90 per cent of the province population living between $1200 \mathrm{~m}$ and $2400 \mathrm{~m}$ above sea level. Highest population densities occur between $1800 \mathrm{~m}$ and $2800 \mathrm{~m}$ above sea level, where land is occupied at around 100 persons per square kilometre.

Table 3.1. Altitude ranges in SHP, by land area, population, and population density on land used for agriculture, 2000

\begin{tabular}{|c|c|c|c|c|c|c|c|}
\hline $\begin{array}{l}\text { Altitude } \\
(\mathrm{m})\end{array}$ & $\begin{array}{l}\text { Land area } \\
\left(\mathrm{km}^{2}\right)\end{array}$ & $\begin{array}{c}\% \% \\
\text { Land area }\end{array}$ & $\begin{array}{l}\text { Land } \\
\text { in use } \\
\left(\mathrm{km}^{2}\right)\end{array}$ & $\begin{array}{c}\% \\
\text { Land } \\
\text { in use }\end{array}$ & $\begin{array}{c}\text { Population } \\
\text { in } \\
2000\end{array}$ & $\begin{array}{c}\% \\
\text { Pop. }\end{array}$ & $\begin{array}{c}\text { Population } \\
\text { Density } \\
\text { per } / \mathbf{k m}^{2}\end{array}$ \\
\hline $0-600$ & 3660 & 14.2 & 219 & 3.08 & 5205 & 0.95 & 24 \\
\hline $600-1200$ & 7854 & 36.6 & 1299 & 18.26 & 32,983 & 6.04 & 25 \\
\hline $1200-1800$ & 7821 & 30.4 & 3878 & 54.53 & 328,964 & 60.22 & 85 \\
\hline $1800-2400$ & 3840 & 14.9 & 1582 & 22.24 & 165,964 & 30.38 & 105 \\
\hline $2400-2800$ & 1095 & 4.3 & 134 & 1.88 & 13,149 & 2.41 & 98 \\
\hline $2800+$ & 1427 & 5.6 & 0 & 0.00 & 0 & 0.00 & No pop. \\
\hline Total Area & 25,698 & 100.0 & 7112 & 100.00 & 546,265 & 100.00 & 77 \\
\hline
\end{tabular}

Source: PNG Resource Information System (PNGRIS); PNG National Census 2000 (NSO 2002). 
Two-thirds of SHP is made up of mountains or hills and almost one third is of volcanic origins (Table 3.2). A broad curving band of limestone influences the landforms of much of the province. A number of large Pleistocene volcanoes have forced their way through the limestone to build large cones; Mt Giluwe is the second highest point in Papua New Guinea at 4160 m, and Mt Ambua and Mt Kerewa are both over $3600 \mathrm{~m}$ high. Other prominent volcanic cones are Mt Ialibu and in the south, rising out of the lowlands, Mt Bosavi. A large elongated lake, Lake Kutubu, lies in a limestone depression in the southeast.

Table 3.2. Landforms in SHP by land area, population, and population density on land used for agriculture, 2000

\begin{tabular}{|c|c|c|c|c|c|c|c|}
\hline Landform & $\begin{array}{l}\text { Land area } \\
\left(\mathbf{k m}^{2}\right)\end{array}$ & $\begin{array}{c}\% \\
\text { Land area }\end{array}$ & $\begin{array}{c}\text { Land } \\
\text { in use } \\
\left(\mathbf{k m}^{2}\right)\end{array}$ & $\begin{array}{c}\% \\
\text { Land } \\
\text { in use }\end{array}$ & Population & \% Pop. & $\begin{array}{c}\text { Population } \\
\text { Density } \\
\text { per } / \mathbf{k m}^{2}\end{array}$ \\
\hline Mountains \& hills & 16,803 & 65.4 & 4433 & 62.33 & 318,822 & 58.36 & 72 \\
\hline Volcanic & 7513 & 29.2 & 2293 & 32.24 & 179,173 & 32.80 & 78 \\
\hline Plains \& plateaux & 894 & 3.5 & 276 & 3.88 & 38,523 & 7.05 & 140 \\
\hline Floodplains & 488 & 1.9 & 110 & 1.55 & 9747 & 1.78 & 89 \\
\hline Total Area & 25,698 & 100 & 7112 & 100 & 546,265 & 100 & 77 \\
\hline
\end{tabular}

Source: PNGRIS; PNG National Census 2000 (NSO 2002).

Agricultural land use follows closely the pattern of landforms, with 95 per cent of agricultural land being on mountains and hills and volcanic landforms. Similarly, 90 per cent of the population of SHP live on these landforms. Population densities are highest on floodplains, but only seven per cent of people live on floodplains. Population densities are relatively high at around 80 people per square kilometre on all landforms.

Table 3.3. Average population growth rates (\% per year), 1966 to 2000: Southern Highlands compared with other Papua New Guinea regions

\begin{tabular}{|c|c|c|c|c|c|}
\hline & $1966-1971$ & $1971-1980$ & $1980-1990$ & $1990-2000$ & $1966-2000$ \\
\hline Southern Highlands & 0.51 & 4.04 & 2.99 & 5.48 & 3.07 \\
\hline Southern Region & 3.35 & 1.81 & 2.72 & 0.21 & 1.84 \\
\hline Highlands Region & 2.07 & 1.95 & 2.05 & 3.65 & 2.49 \\
\hline Momase Region & 2.35 & 2.30 & 1.82 & 3.36 & 2.48 \\
\hline Islands Region & 3.59 & 2.40 & 2.90 & 2.30 & 2.69 \\
\hline Papua New Guinea & 2.61 & 2.09 & 2.25 & 3.24 & 2.55 \\
\hline
\end{tabular}

Notes:

Growth rates are calculated as follows: $\log \mathrm{N}(\mathrm{Pn})-\log \mathrm{N}(\mathrm{P} 0) /$ inter-censual period $\times 100$. The inter-censual periods used are 1966-1971, 5 years; 1971-1980, 9.1 years; 1980-1990 9.92 years; 1990-2000, 9.92 years; 1966-2000, 33.94 years.

National Capital District is included in Southern Region from 1966-1980 and is excluded after that. Sources: 1966-1990: DNPN (1999); PNG National Census 2000 (NSO 2002).

The 2000 National Census suggests that the SHP population is the largest provincial population in the country. However censuses in SHP have been 
problematic for some decades, with the provincial population fluctuating wildly between censuses (Table 3.3; Figure 3.1). The rapid increase between 1966 and 1971 is explained by a large number of communities being censused for the first time, but the 1980 to 1990 decrease in population is probably the result of a serious undercount in 1990. The addition of 229,000 people in the 10 years between 1990 and 2000 would appear to be the outcome of a combination of an undercount in 1990 and an over count in 2000. An increase in the population of more than 42 per cent in the 10 years between 1990 and 2000 is not possible, especially as other census information indicates that at least since 1980, when the first data is available, SHP has lost more people from migration than it has gained.

Figure 3.1. Average population growth rates (\% per year), 1966 to 2000: Southern Highlands compared with Papua New Guinea regions

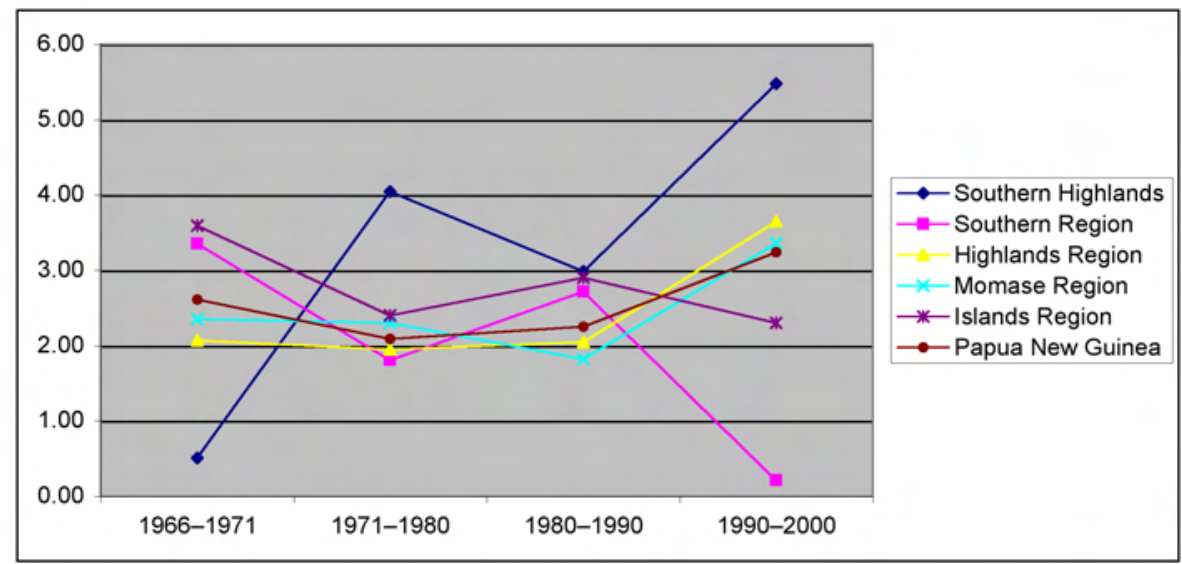

Source: DNPM (1999: Appendix A4); PNG National Census 2000 (NSO 2002).

The sources of this over-counting can be guessed at if the 1980 SHP district populations are projected at 1.5 per cent per year and the projected populations are compared with the censused populations in 2000 (Figure 3.2). The 2000 populations of Ialibu-Pangia and Tari-Pori are smaller in 2000 than the projection suggests they should be. On the other hand, the 2000 censused populations of Mendi-Munihu and Nipa-Kutubu are significantly larger than predicted by their 1980 populations, so it would be appear that the over-counting occurred mainly in these districts.

Sixteen linguistic groups occupy SHP. In the far west are the Hewa, who live in small and relatively mobile communities in the upper Strickland Valley. To their south are the large and related Duna, and Huli speakers in the Kopiago area and in the Tari Basin and surrounding uplands and valleys. More people speak Huli in SHP than any other language. The Huli cross a major physical divide formed by Mt Ambua into the Nembi Valley where they border the Mendi 
speakers who extend east into the Lai and Mendi valleys and uplands. To their east, the Kewa, Wiru and Hagen speakers live along the southern side of Mt Giluwe and around Mt Ialbu. The Hagen speakers go northeast into Western Highlands Province. In the south of the province in the lowlands ${ }^{1}$ live the Onabasulu, Sonia, Kasua, Kaluli around Mt Bosavi and the Fasu and Foi around Lake Kutubu. In the southwest are Sau and Porome speakers, small groups living in rugged and isolated limestone valleys. Political schisms occur along language boundaries but geography is also important. Serious political struggles have developed between Duna and Huli speakers in the west, who have threatened to form their own province (see Haley, this volume), Mendi speakers in the centre and Kewa and Wiru speakers in the east. Small and isolated language groups like the Hewa and Onabasulu have no power or representation, although the discovery of gas at Lake Kutubu has recently catapulted Fasu and Foi speakers into provincial and national prominence.

Figure 3.2. SHP Districts: Predicted population change 1980-2000 verses censused population in $\mathbf{2 0 0 0}$

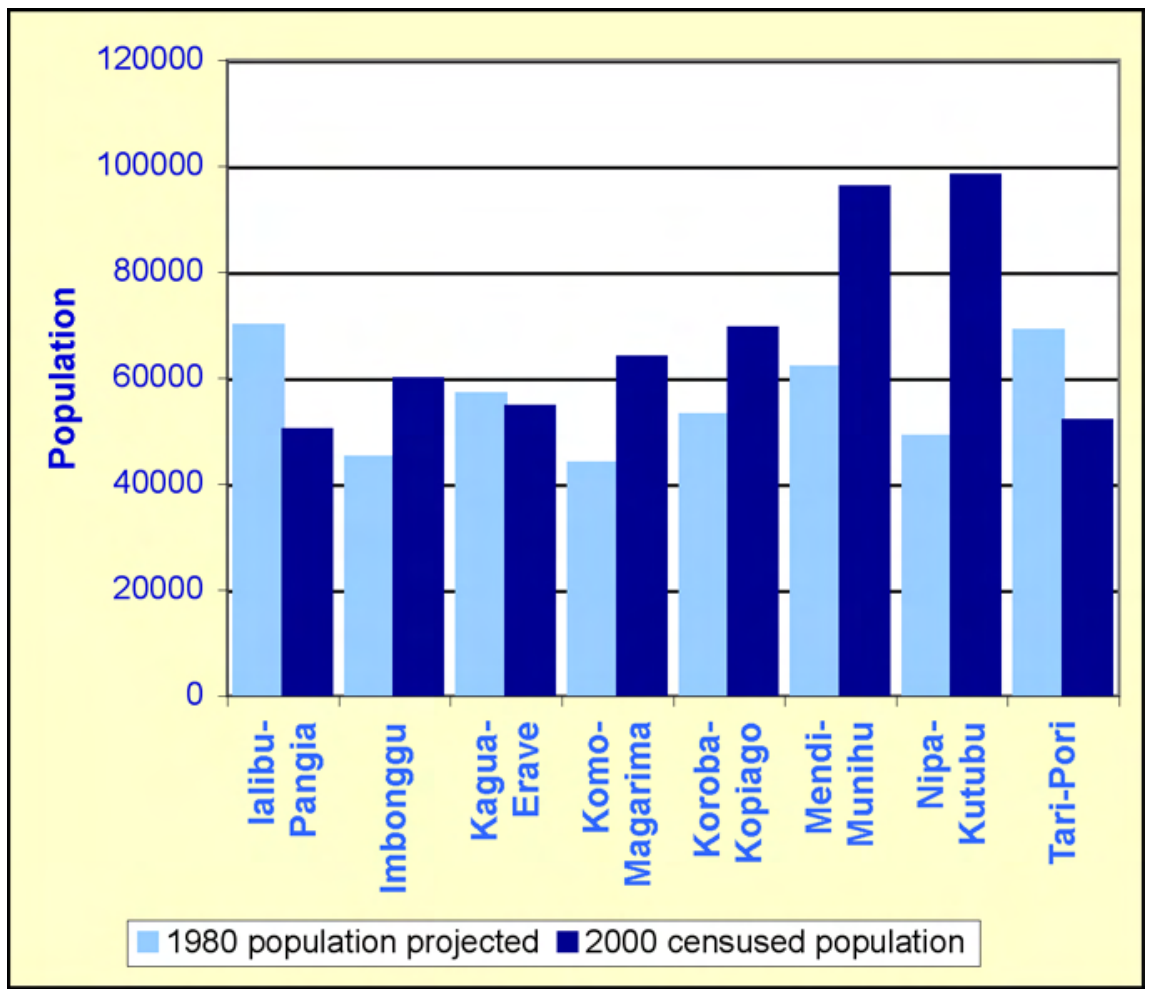

Source: PNGRIS; PNG National Census 2000 (NSO 2002). 
More than 80 per cent of the SHP is of very low or low quality for the production of sweet potato (Table 3.4, Figure 3.3). Less than two per cent of the total land area of SHP is high quality land. More than 75 per cent of the SHP population, however, is concentrated on low and medium quality land, with a further 10 per cent on high or very high quality land.

Table 3.4. Land quality by land area and populations

\begin{tabular}{|c|c|c|c|c|}
\hline Land quality & Land Area $\mathbf{( k m}^{\mathbf{}} \mathbf{)}$ & \% of land area & Population & \% of Population \\
\hline Very low & 6583 & 25.6 & 71,327 & 13.1 \\
\hline Low & 14,848 & 57.8 & 271,214 & 49.6 \\
\hline Moderate & 3877 & 15.1 & 139,518 & 25.5 \\
\hline High & 356 & 1.4 & 52,152 & 9.5 \\
\hline Very High & 35 & 0.1 & 12,054 & 2.2 \\
\hline Total & 25,698 & 100 & 546,265 & 100 \\
\hline
\end{tabular}

Source: PNGRIS; PNG National Census 2000 (NSO 2002).

The higher quality land in SHP is predominantly located in the Ialibu-Pangia district, with other smaller areas of high quality land being found in and around Tari, in the Mendi district and in the Koroba-Lake Kopiago district.

\section{Figure 3.3. Land quality}

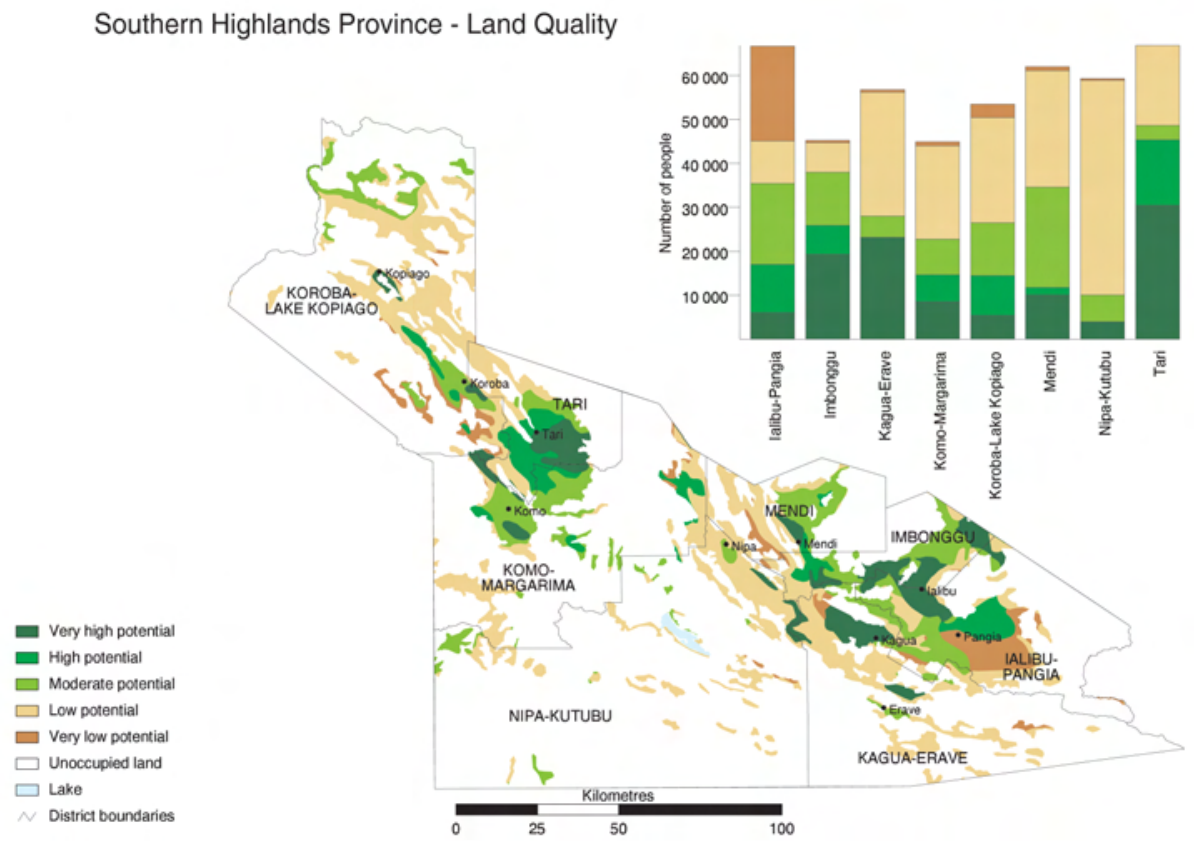

Source: Hanson et al (2001:95) 
SHP agriculturalists improve low and medium quality land by drainage, mounding and composting, enabling them to produce enough sweet potatoes to support high human population densities and large pig herds. Their ingenuity, however, cannot overcome cold temperatures at altitudes above $2800 \mathrm{~m}$, steep slopes and cloudiness. SHP is one the cloudiest provinces in Papua New Guinea and agricultural production is constrained by lack of sunshine in many parts of the province.

SHP agriculture (Figure 3.4) is dominated by high intensity sweet potato production for pigs and food. It ranges in intensity from continuous cultivation at Tari, where composted mounds are used, to cultivation periods of up to twenty years at Nembi, Mendi, Ialibu, Kagua and Erave, where circular mounds and long beds without composting are used to grow sweet potato. To the northwest and the southeast, agriculture is low intensity shifting cultivation, but is still dominated by sweet potato. Only in the south is agriculture not the most important source of food. There sago is the most important food, supplemented by very low intensity shifting cultivation.

\section{Figure 3.4. Agricultural systems}

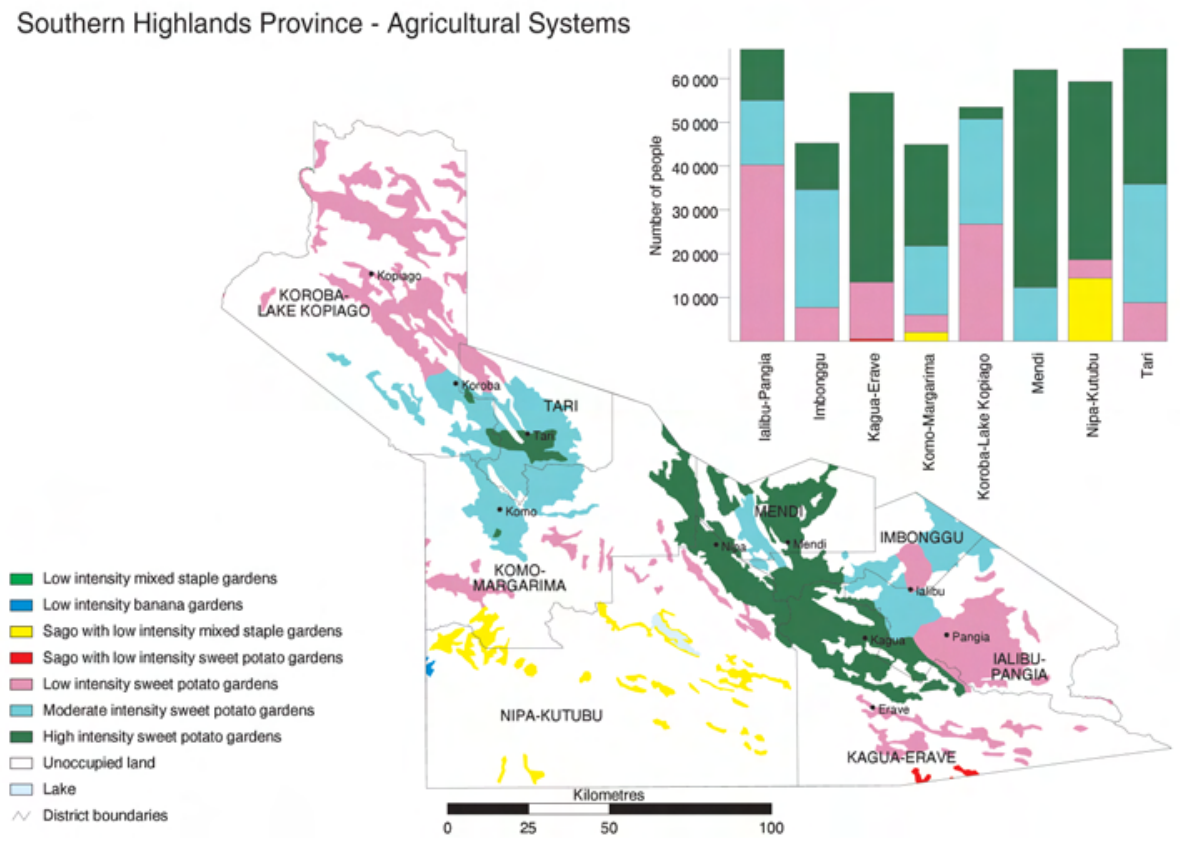

Source: Hanson et al (2001:94)

Unlike many of the agricultural systems to the east in the Wahgi Valley, and to the north in Enga, SHP systems have yet to develop strong cash cropping components. Coffee is only important in the east, close to Mt Hagen. Small coffee 
gardens exist at Tari and in the Mendi and Lai valleys, but production is very low and coffee husbandry of poor quality.

This inability of SHP agricultural systems to generate cash incomes is a serious constraint on rural development in the province. The World Bank-funded Southern Highlands Rural Development Project planted large areas of coffee and tea in various parts of the province in the 1970s, but today none of these areas is productive. This means that the great majority of rural people in SHP receive estimated cash incomes of less than K20 per year (Figure 3.5). The only places where rural incomes are higher are the Ialibu area, where people have coffee and good access to the Mount Hagen fresh food markets, and around Lake Katubu, where people receive royalty monies from the local oil and gas projects.

\section{Figure 3.5. Estimated rural cash incomes 1996}

\section{Southern Highlands Province} Rural Cash incomes 1996
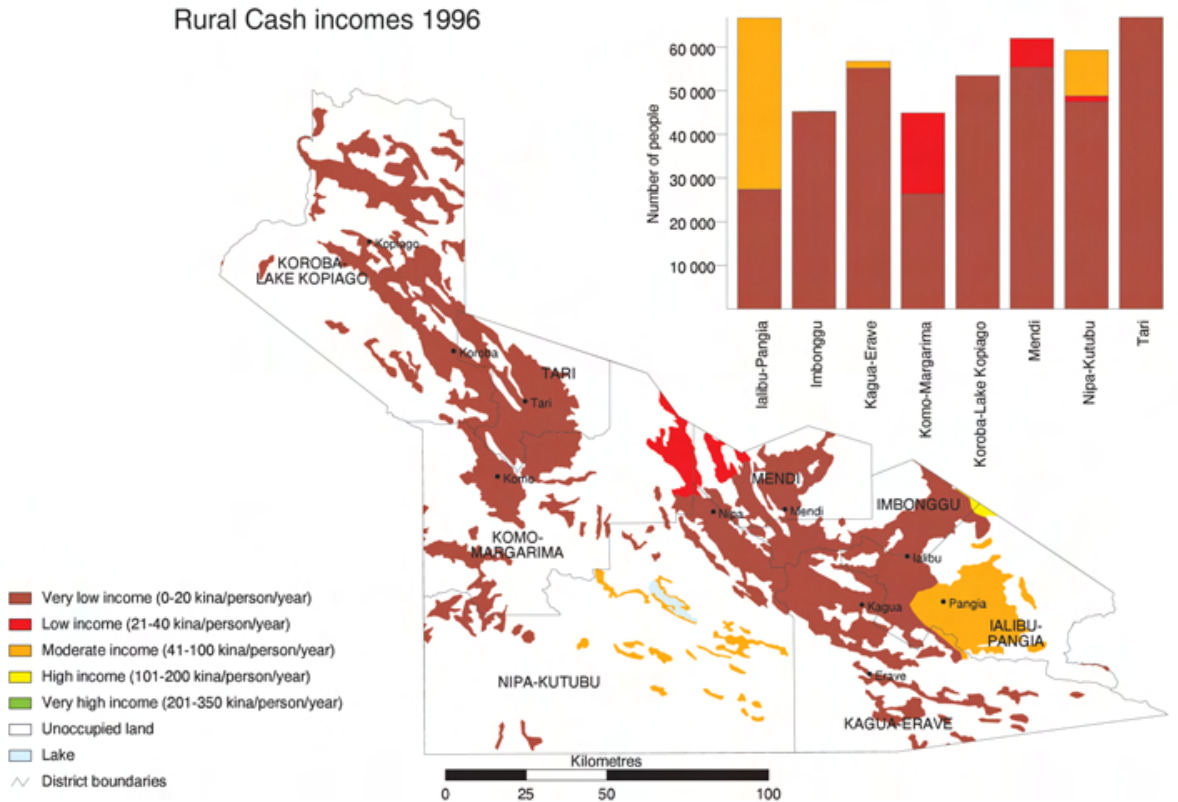

Source: MASP; Hanson et al (2001:93)

Royalty moneys aside, cash incomes in SHP are closely associated with accessibility to markets and services centres, which is in turn associated with the location of roads (Figure 3.6). People living in the northwest, southwest and southeast corners of the province are more than one day's travel from any service centre. By contrast, people in the northeast are within four hours' travel of a major service centre, namely Mendi or Mount Hagen. The central parts of the province are within eight hours' travel of a service centre. 
Figure 3.6. Access to service centres and markets

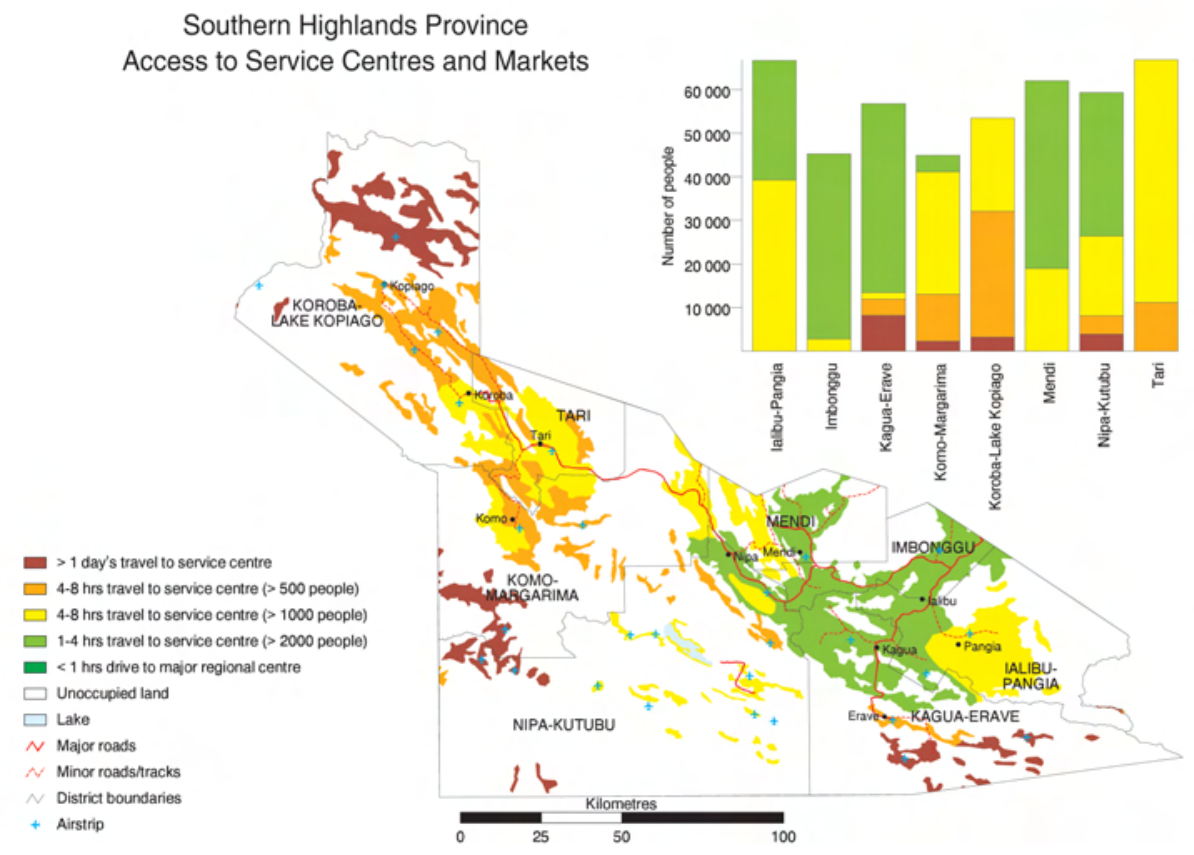

Source: Hanson et al (2001:92)

The combination of relatively high population densities, high-intensity agriculture and poor environments is resulting in pressure on land in some parts of SHP that will lead to land degradation in the short to medium future. The most critical areas of land pressure occur in the Mendi, Nipa-Kutubu and Komo-Magarima districts (Figure 3.7). On the other hand, there are areas at Tari, Kagua, Erave, Komo and Mendi that could support higher-intensity land use.

The combination of relatively poor environments and low cash incomes is also reflected in patterns of child malnutrition. The most recent survey of malnutrition in children under five years of age in SHP was the National Nutrition Survey of 1982-83 (Heywood et al 1988). When the results of this sample survey are extrapolated over the whole of Papua New Guinea and recalculated into the 2000 districts, SHP children are shorter for their age than most other children in Papua New Guinea, but are reasonably heavy for their length. Stunting, significantly low length-for-age, is an indication of long-term or chronic malnutrition, whereas low weight is an indication of short-term nutritional problems. In 1982-83, children in Koroba-Lake Kopiago District were the shortest children in Papua New Guinea, but for their length they were the heaviest. Komo-Magarima and Mendi children were also among the shortest children in Papua New Guinea but were also heavier than most children of their length. 
Notably, the only children in SHP that were of average height and were above average weight were those in Ialibu-Pangia and Imbonggu districts, where cash incomes are highest and there is better access to services and markets. This association between malnutrition and environment has also been shown to exist on a more local scale; at Tari, children whose mothers live in poorer environments are born on average $300 \mathrm{~g}$ lighter than children whose mothers live in better environments (Allen 2002).

\section{Figure 3.7. Agricultural pressure and potential}

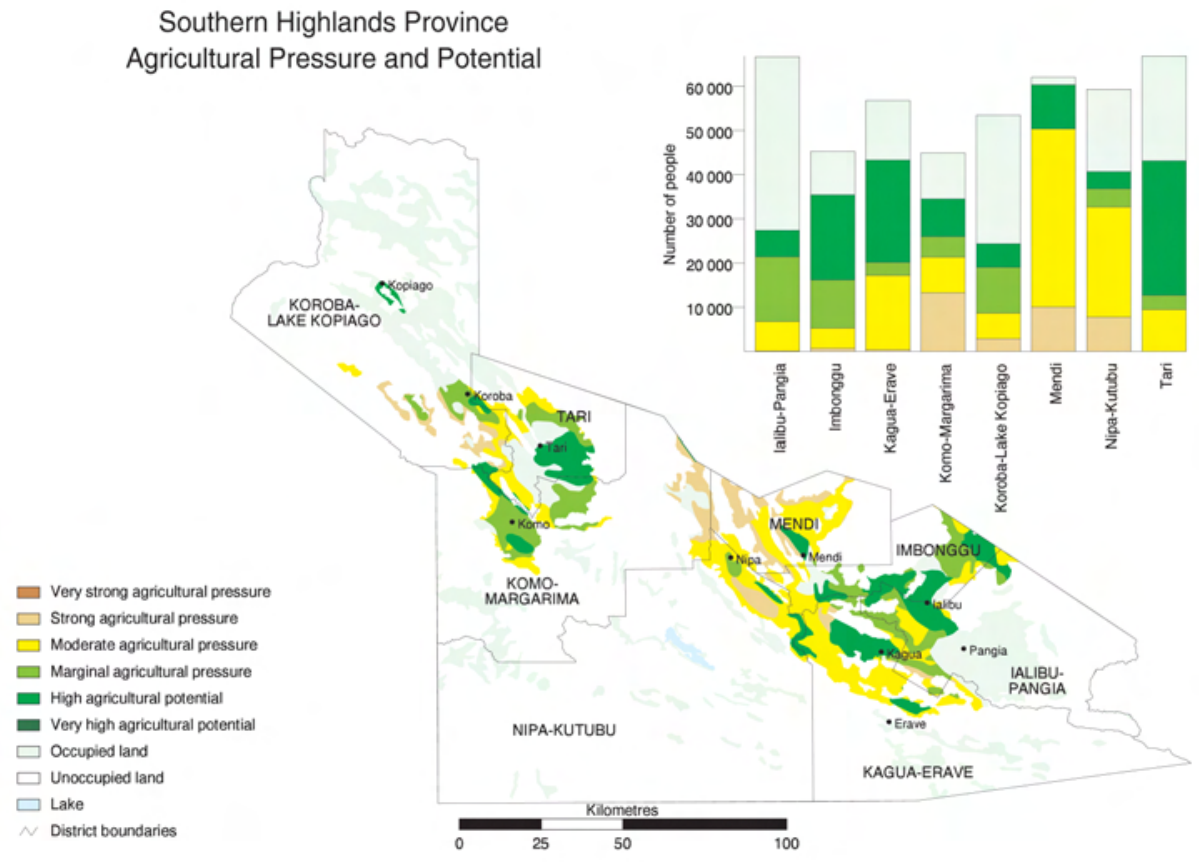

Source: Hanson et al (2001:96)

Trends in child nutrition are also reflected in literacy rates in SHP. Everywhere in the province more men than women are literate, and a greater proportion of adults, male and female, are literate in Ialibu-Pangia and Imbonggu districts, than elsewhere in the province (PNG 2000 National Census, household data files). However, nowhere in SHP are more than 50 per cent of adults literate. 
Figure 3.8. Literacy rates by district

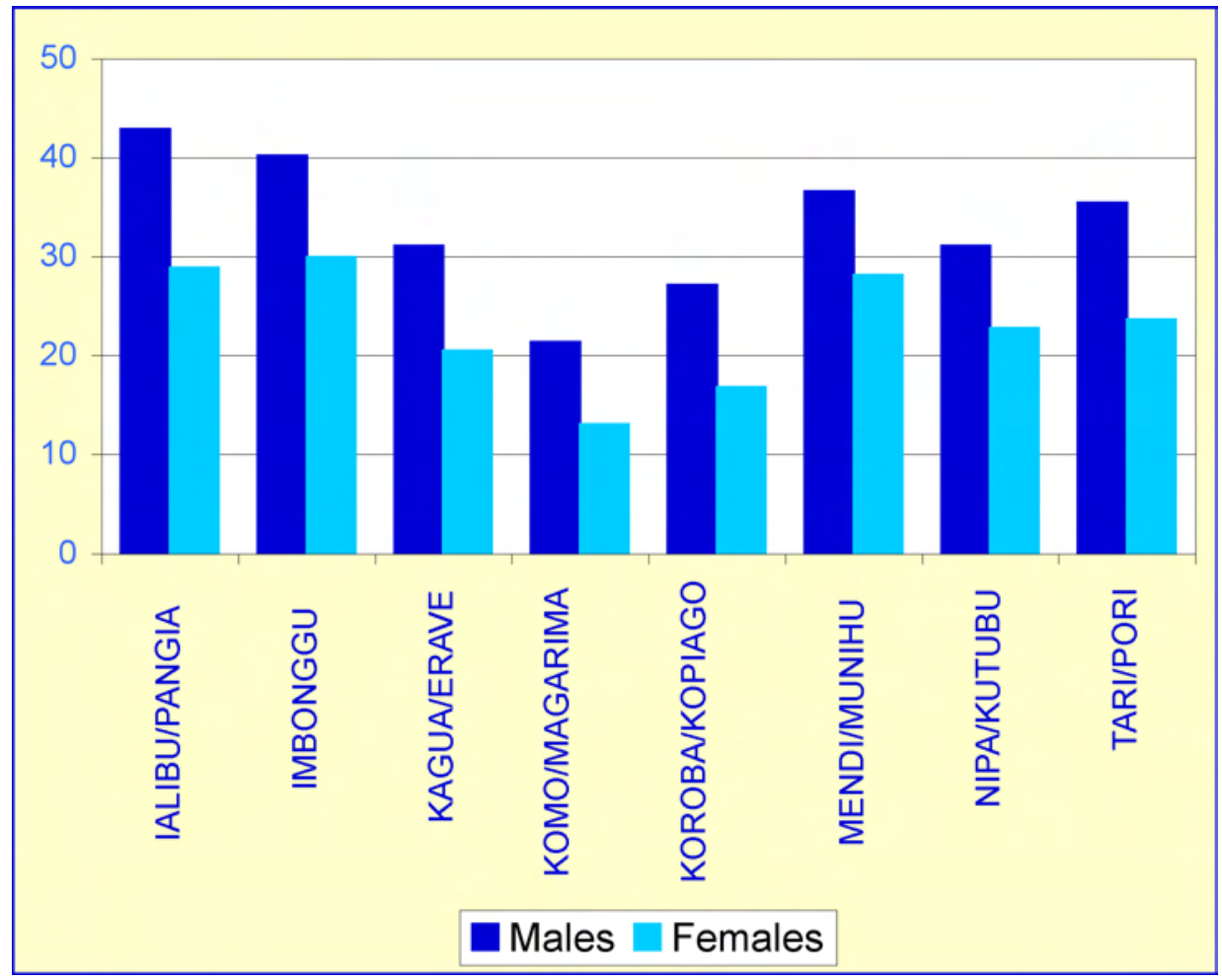

Source: PNG National Census 2000 (NSO 2002)

The three major components of disadvantage - poor environment, low cash incomes and poor access to markets and services - are summarised in Figure 3.9. This shows areas of 'disadvantage' in SHP (Hanson et al 2001). The most disadvantaged people in SHP are those on the Nembi Plateau and in the higher fringes of the Mendi Basin, where agricultural pressure on land is strong, incomes are very low, and population densities are high. People in these areas are vulnerable to land shortages and subsistence food shortages, and have little cash available to buy supplementary foods. Large numbers of people in the Wage and Lai valleys face similar disadvantages, but their incomes are slightly higher. The upper fringe areas of the Tari Basin earn low incomes and have moderate pressure on their land. Smaller numbers of people in the Lagaip Valley in the northwest, in the lower Erave Valley and in the Mt Bosavi area in the southwest, have poor access to services and poor agricultural environments, but populations are small and there is little pressure on land. Few opportunities to improve livelihoods exist in these areas. The Kopiago area is also an area of disadvantage. With the exception of the wetland areas surrounding Lake Kopiago, the 
environment is poor, as is access to services. Added to this, incomes are very low.

\section{Figure 3.9. Disadvantaged areas}

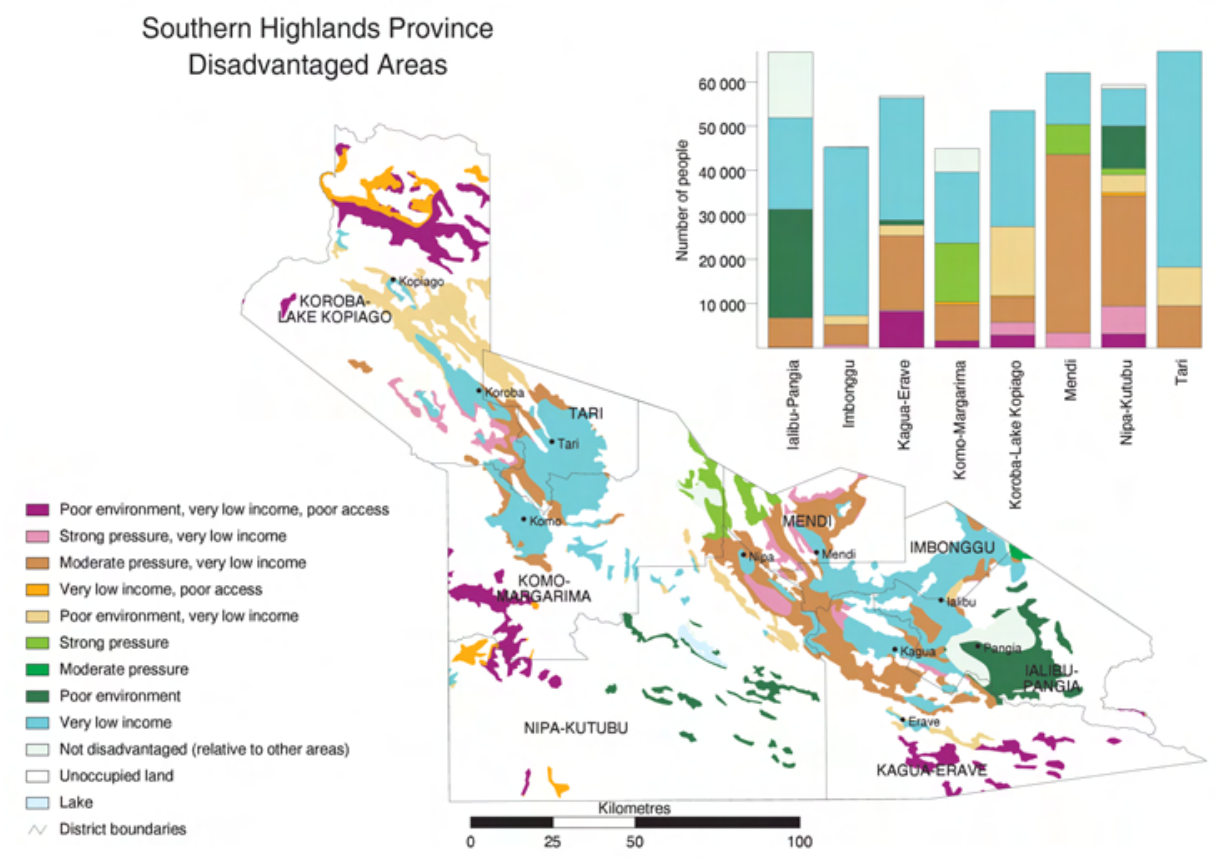

Source: Hanson et al. (2001:97)

\section{Conclusion}

Large numbers of people in SHP are increasingly vulnerable to declining crop yields and food shortages, due to a combination of poor agricultural environments, high population densities and intensive agriculture. Compared with their counterparts elsewhere in Papua New Guinea, many Southern Highlanders are particularly disadvantaged: incomes are low throughout the province and most people lack the capacity to purchase supplementary food. Compounding this is the fact that cash crop development is hindered by major environmental constraints and very poor access to markets.

\section{References}

Allen, B. J. 2002 'Birthweight and environment at Tari', Papua New Guinea Medical Journal 45(1-2):88-98.

Department of National Planning and Monitoring (DNPM), Papua New Guinea. 1999 Papua New Guinea National Population Policy 2000-2001. Waigani: Population and Human Resources Branch, Sectoral Coordination Division, DNPM. 
Hanson, L. W., Allen, B. J, Bourke, R. M. and. McCarthy, T. J. 2001 Papua New Guinea Rural Development Handbook. Land Management Group, The Australian National University. Canberra.

Heywood, P., Singleton N. and Ross, J. 1988 'Nutritional status of young children - the 1982/83 National Nutrition Survey', Papua New Guinea Medical Journal 31:91-101.

National Statistical Office, Papua New Guinea (NSO). 2002 National Thematic Map Tables, PNG 2000 National Census on CD-ROM. Waigani: NSO.

Wurm, S. and Hattori, S. 1981-83 Language Atlas of the Pacific Area. Linguistics Series C, Part 1. Canberra: Australian Academy of the Humanities.

\section{ENDNOTES}

${ }^{1}$ Foe in current Papua New Guinea government usage. 